\title{
Environmental Air Quality and Health: Evidence from Trade Liberalization
}

\author{
Amirhooshang Navaei ${ }^{1 *}$, Farhad Farnoud ${ }^{2}$ \\ ${ }^{1}$ Fundamental Analyst, Omid Financial Group 15th floor ,Sayeh Tower, Valiasr St., Tehran, IRAN \\ ${ }^{2}$ Chief Operating Officer, Mahtaabsazan Iranian Charity Foundation, Unit 5, No. 3, Nader Alley, South Bahar St., Sadr Highway, Tehran, \\ IRAN \\ E-mail for correspondence: a.navaei@omid.ir
}

\begin{abstract}
This paper explores the potential externality of trade liberalization between the US and China on air pollution and infants' health outcomes. Exploiting the differential impact of tariff reductions due to trade liberalization across industries combined with compositional variations of industry-specific employment across counties as the main source of identification strategy and using the universe of birth records in the US over the years 1990-2017 (over 97 million observations), we document substantial improvements in birth outcomes of mothers residing in counties with higher exposure to trade policy change. The exposed counties experienced sharp drops in employment specifically for manufacturing industries and revealed sharp reductions in a wide array of pollutants. A 1 percent reduction in tariff rates is associated with an 11.5 and 12.7 percentage point reduction in the likelihood of low birth weight and preterm birth, respectively.
\end{abstract}

Keywords: Trade Liberalization, Pollution, Air Quality, Health, Fetal Origin Hypothesis, Birth Outcomes, Panel Data, Environmental Health

JEL Codes: F18, F64, O24, Q27, H75, J13

\section{INTRODUCTION}

It is well established that the health environment and external shocks during prenatal development have the potential to influence birth outcomes. Fetal Origin Hypothesis provides a theoretical framework based on epigenetic programming to explain this link (Almond and Currie, 2011a, 2011b; Barker, 1990). While human genomes are very similar across different individuals their Epigenome is different. An epigenome is a group of chemical compounds that are attached to the DNA in order to silence off or turn on some genomes for specific reasons. Epigenome acts like software while genome acts as hardware. The main reason that drives the programming of the Epigenome is environmental factors. For instance, a sharp increase in pollution signifies a worsening environment and persuades the reproductive system of the mother to re-program the Epigenome with the main purpose of survival of the fetus. It can do that by, for instance, attaching a methyl molecule to the genes related to growth and turns them off. The result is a survived infant but low in health endowment. A relatively large body of the literature documents the link between antenatal health environment and birth outcomes (Chatterji et al., 2014; Janet Currie et al., 2009; Hoynes et al., 2015; Leonard and Mas, 2008; Lindo, 2011; NoghaniBehambari, Noghani, and Tavassoli, 2020; NoghaniBehambari, Noghani, Tavassoli, et al., 2020; Sonchak, 2015; Tavassoli et al., 2020; Wherry et al., 2018).

In the year 2000, China entered the World Trade Organization (WTO) and was able to increase its exports to the US by benefiting from lower tariff rates as a member of the WTO. The acute decrease in tariff rates, however, was not uniformly distributed across industries. For instance, the US imports of manufacturing and mining products experienced a large increase due to large reductions in trade barriers while imports in other industries did not. Since the manufacturing and mining sectors are among the main pollutant industries (Beach and Hanlon,

2016; Tavassoli et al., 2020), the trade liberalization had the potential to reduce local pollution and improve air quality 
(Ederington et al., 2004; Forslid et al., 2017; Gale IV, 1995). Since pollution is among the main environmental factors that affect infants' health outcomes, it is arguable that a reduction in tariffs due to trade liberalization has the potential to improve birth outcomes. This paper aims to fill this gap in the literature.

Exploiting the differential impact of tariff reductions across industries combined with compositional variations of industry-specific employment across counties as the main source of identification strategy and using the universe of birth records in the US over the years 1990-2017 (over 97 million observations), we explore the link between trade liberalization, pollution, and birth outcomes. We find that the trade liberalization reduced employment in manufacturing, mining, and construction industries and reduced industrial pollution. Besides, it improved birth outcomes and a wide range of infants' health measures. One standard deviation in tariff gaps is associated with an increase of 17 grams in birth weight and a 2.2 percentage point higher likelihood of being born with low birth weight. These effects are statistically significant for all health measures even after controlling for a full set of fixed effects, a wide range of socioeconomic covariate, parental characteristics, and state-by-year trend.

Evaluating the health externalities of pollution has important policy implications. It quantifies the external costs of industrial pollution and helps policymakers to design the optimal structure of pollution abatements. Besides, since the main source of shock to pollution in this study comes from trade liberalization, the results of this paper could help policymakers to re-evaluate the benefits of trade and optimize the tariff rates considering the positive externalities of trade liberalization for the health of infants.

This paper adds to the literature in two ways. First, to the best of our knowledge, this is the first study to assess the health benefits of trade liberalization in the case of birth outcomes. Second, it adds to the literature on the Fetal Origin Hypothesis by providing evidence of a sharp reduction in pollution due to trade liberalization on infants' health outcomes.

The rest of the paper is organized as follows. In section 2, we go over a brief literature review. Section 3 provides a background on US-China trade liberalization. Section 4 discusses the data sources and construction of the final sample. The econometric strategy is discussed in section 5 . The main results are reported in section 6 . We depart some concluding remarks in section 7 .

\section{LITERATURE REVIEW}

Trade liberalization has the potential to affect outcomes beyond the labor market. Pierce and Schott (2020) show that areas that were exposed to the economic effects of international trade experienced more deaths mainly due to fatal drug overdoses and specifically among whites. This increase in mortality coincides with worsening labor market conditions and the uptake of disability insurance. Olper et al. (2018) applies a synthetic control method on a panel of emerging and developing countries and show that an increase in trade openness reduces child mortality. On average, ten years after trade liberalization, child mortality decreases by about 9 percent. Autor et al. (2019) document that the shocks to the labor market due to trade liberalization reduced marriage and fertility and increased the number of children living in single-parent families. Dix-Carneiro et al. (2018) explore the effect of trade liberalization on crime rates in Mexico. The trade shock changed labor market conditions, provision of public goods, and income inequality. Through these channels, it increased crime rates in areas that were more exposed to trade shocks. Feng et al. (2021) explore the effect of reductions in export tariffs on Chinese workers and showed that trade liberalization improved the health of low educated workers who reside outside of urban areas.

Noghani and Noghanibehambari (2019) explore the effect of trade liberalization in the US between the years 19902010 on corporate governance measures and managerial slack. They apply a difference-in-difference identification strategy and use a longitudinal panel of all firms in the US and show that trade openness was successful to improve measures of governance and reduce managerial wasteful activities. Colantone and Stanig (2018) investigate the effect of trade liberalization on electoral outcomes and opinions toward nationalism across 15 western European countries over the years 1988-2007. They find that areas that were affected more strongly by import shocks revealed higher preferences towards candidates with nationalist and isolationist ideas.

Environmental consequences are among the highly debated aspects of trade liberalization and globalization. In a seminal paper, Antweiler et al. (2001) develop a theoretical model to link free trade and environmental pollution. They show that trade liberalization decreases pollution through changes in trade-induced technologies across industries. In a similar study, Cherniwchan (2017) documents the environmental effects of NAFTA and trade liberalization in the US. They show that NAFTA was responsible to sharp reduction in sulfur dioxide and matriculate matter (PM10) in manufacturing sector. These changes were driven by within-plant responses to NAFTA rather than a compositional change in local industries. Other studies confirm the fact that trade liberalization can indeed improve environmental quality (Benarroch and Gaisford, 2014; Copeland, 2013; Forslid et al., 2017, 2017; Fung and Maechler, 2007; Gale IV, 1995; Ghani, 2012; Hu and McKitrick, 2016; Hubbard, 2014; Shen, 2008).

Pollution is among the main external stressors during prenatal development with a sizeable influence on birth outcomes. Currie et al. (2009) explore the effects of air pollution on infants' health outcomes. They use the information of the exact address of mothers and match 
with the nearest air monitor. Including maternal fixed effects to control for all time-invariant attributes of mothers, they show that exposure to carbon monoxide is associated with negative birth outcomes with the larger effects for smoking mothers and older mothers. Hill (2018) explores the effect of the shale gas boom in Pennsylvania on infants' health outcomes. She finds that gas production increases pollution which in turn has negative effects on birth outcomes. In a reduced form analysis, she finds that an additional gas well is associated with a 7 percent rise in low birth weight. Tavassoli et al. (2020) explore the effect of sharp rises in industrial pollution during the $19^{\text {th }}$ century on pollution and find that the pollution-driven rise from the upswing in the manufacturing sector was associated with rises in infant mortality and changes in sex composition of infants to more females. They argue that this fact signifies higher incidences of fetal deaths. Several studies show that health, socioeconomic conditions, environmental factors, and mental conditions of the pregnant mother also have the potential to influence birth outcomes (Aizer and McLanahan, 2006; Chatterji et al., 2014; Chou et al., 2010; Cole and Currie, 1993; Corman et al., 2019; J. Currie and Moretti, 2003; Janet Currie et al., 2009; Figlio et al., 2014; Gage et al., 2013; Hoynes et al., 2015; Joyce, 1999; Lindo, 2011; NoghaniBehambari, Noghani, Tavassoli, et al., 2020; Noghanibehambari and Salari, 2020; Rosenzweig and Wolpin, 1995; Rossin, 2011; Torche, 2011).

\section{BACKGROUND On US-China TRADE RELATIONS}

The United States has a trade treaty with members of the World Trade Organization (WTO). The members can benefit from relatively low tariff rates under the definition of Normal Trade Relations (NTR) rates while non-member countries face higher tariff rates under the definition of Non-NTR rates. However, Congress has the right to make a temporary exception for these non-market economies and grant them the NTR status so that they trade with the US under considerably lower tariff rates. Congress gave this permission to China on an annual basis as far back as 1980. However, the temporary nature of the NTR status generated uncertainty for Chinese firms. This uncertainty was exacerbated with political tensions during 1990 and specifically the China-Pakistan missile deal of 1993 and the Taiwan Strait crisis of 1995-1996. These uncertainties were eliminated when China became a member of the WTO in 2000. The differences between NTR rates, under which China started to trade with the US after 2000, and NonNTR rates, to which China was exposed before 2000, varied substantially across industries with larger differences being concentrated among manufacturing, mining, and construction industries (Pierce and Schott, 2020). These industries that were previously protected with Non-NTR tariff rates became exposed to the competition with Chinese industries after 2000. We use this source of variation as the primary shock to pollution in our identification strategy since it has been documented that these industries are among the main pollutant industries (Beach and Hanlon, 2016; Hill, 2018; Tavassoli et al., 2020).

\section{Data SOURCES}

This study uses a wide array of data sources. The primary data source is birth certificate data from the National Center for Health Statistics. It reports the data on infants' health measures, mother's characteristics, father's characteristics, and mother's health utilization during pregnancy. We use ten different measures of infants' health that are explained here. Birth Weight is measured in grams. Full-Term Birth Weight is the birth weight for newborns who were born between 37-42 weeks of gestation. Low Birth Weight is a dummy that equals one if birth weight is less than 2500 grams. Very Low Birth Weight is a dummy that equals one if birth weight is less than 1500 grams. Small for Gestational Age is a dummy that equals one if the birth weight is at the bottom $10^{\text {th }}$ percentile of the birth weight distribution specific to its gestational age. Gestational Age is measured in weeks. Preterm Birth is a dummy that equals one if gestational age is less than 37 weeks. Apgar score is an index consisting of five indexes that each varies between zero and 2 and so the Apgar score varies between zero to ten. Low Apgar Score is a dummy that equals one if the Apgar score is less than 8. Fetal growth is the average of weekly intrauterine growth.

The data on pollution reported by the Environmental Protection Agency is extracted from replication data provided by Tavassoli et al. (2020). Since pollutants have different units of measurement and these units are mostly non-intuitive, to ease the interpretation we standardize each variable by subtracting it from the mean and dividing it by its standard deviation. The data on NTR and NonNTR rates by industry is extracted from Feenstra et al. (2002). The industry-specific employment data is based on annual releases of the Quarterly Census of Employment and Wages and is extracted from Tavassoli et al. (2020).

County and state covariates are withdrawn from the following sources. The county demographic, population, and racial composition are from SEER (2019). The welfare payments are extracted from Pierson et al. (2015). The employment and labor force data are from the Bureau of Labor Statistics. The personal income and Gross State Product (GSP) variables are extracted from the Bureau of Economic Analysis. The minimum wage data is extracted from replication materials provided by Noghani and Noghanibehambari (2019).

Table 1 reports the summary statistics of the final sample. The sample consists of $97,802,424$ births across all US counties over the years 1990-2017. On average, 7.2 percent of births are categorized as low birth weight and 17.8 percent of infants are born prematurely. The average of NTR-Gap across all industries is 0.04 percent with a maximum of 3.8 percent. 
Table 1: Summary Statistics

\begin{tabular}{|c|c|c|c|c|c|}
\hline Variable & Observations & Mean & Std. Dev. & Min & Max \\
\hline \multicolumn{6}{|l|}{ Infant Characteristics: } \\
\hline Birth Weight (grams) & $97,802,424$ & 3327.982 & 602.795 & 227 & 8165 \\
\hline Gestational Weeks & $97,802,424$ & 39.043 & 2.700 & 17 & 52 \\
\hline $\operatorname{Sex}(f=1)$ & $97,802,424$ & 0.488 & 0.497 & 0 & 1 \\
\hline Apgar Score & $84,604,624$ & 8.972 & 0.838 & 0 & 10 \\
\hline Term Birth Weight & $73,571,804$ & 3447.394 & 482.650 & 227 & 8165 \\
\hline Low Birth Weight & $97,802,424$ & 0.072 & 0.259 & 0 & 1 \\
\hline Extremely Low Birth Weight & $97,802,424$ & 0.013 & 0.113 & 0 & 1 \\
\hline Small for Gestational Age & $97,802,424$ & 0.102 & 0.302 & 0 & 1 \\
\hline Preterm Birth & $97,802,424$ & 0.178 & 0.382 & 0 & 1 \\
\hline Low Apgar Score & $84,604,624$ & 0.031 & 0.175 & 0 & 1 \\
\hline Fetal Growth & $97,802,424$ & 85.090 & 14.136 & 4.906 & 361.882 \\
\hline Extremely Preterm Birth & $97,802,424$ & 0.007 & 0.083 & 0 & 1 \\
\hline \multicolumn{6}{|l|}{ Mother Characteristics: } \\
\hline Age & $97,802,424$ & 26.465 & 5.886 & 10 & 54 \\
\hline Race: White & $97,802,424$ & 0.796 & 0.402 & 0 & 1 \\
\hline Race: Black & $97,802,424$ & 0.160 & 0.367 & 0 & 1 \\
\hline Unmarried & $97,802,424$ & 0.283 & 0.450 & 0 & 1 \\
\hline Education (Years of Schooling) & $97,802,424$ & 12.625 & 2.654 & 0 & 17 \\
\hline Month Prenatal Care Began & $97,802,424$ & 2.596 & 1.517 & 0 & 9 \\
\hline Prenatal Visits & $97,802,424$ & 11.179 & 4.025 & 0 & 49 \\
\hline \multicolumn{6}{|l|}{ County Characteristics: } \\
\hline NTR Rate (\%) & $97,802,424$ & 0.003 & 0.024 & 0 & 1.916 \\
\hline NTR Gap (\%) & $97,802,424$ & 0.0402 & 0.1826 & 0 & 3.851 \\
\hline Personal Income per capita & $97,802,424$ & 371.483 & 66.910 & 212.533 & 624.262 \\
\hline \%Blacks & $97,802,424$ & 12.653 & 8.174 & .222 & 69.376 \\
\hline \%Whites & $97,802,424$ & 83.354 & 8.514 & 27.002 & 99.301 \\
\hline \%Males & $97,802,424$ & 48.827 & 0.709 & 46.263 & 53.005 \\
\hline \%Population 25-65 & $97,802,424$ & 50.716 & 2.344 & 40.368 & 55.143 \\
\hline Labor Force Participation rate & $97,802,424$ & 48.237 & 6.557 & 13.250 & 98.976 \\
\hline \%Manufacturing & $97,802,424$ & 0.042 & 0.032 & 0 & 0.210 \\
\hline Unemployment Rate & $97,802,424$ & 6.203 & 2.897 & .575 & 38.233 \\
\hline County Population & $97,802,424$ & 91842.714 & 292157.900 & 61 & 10018600 \\
\hline Average Weekly Wage & $97,802,424$ & 605.573 & 142.338 & 44.338 & 1928.103 \\
\hline \multicolumn{6}{|l|}{ State Characteristics: } \\
\hline GSP per capita & $97,802,424$ & 43585.268 & 9031.635 & 24371.631 & 140143.05 \\
\hline Log Current Transfer Receipt & $97,802,424$ & 18.080 & 0.991 & 14.495 & 19.850 \\
\hline Log Income Maintenance Benefits & $97,802,424$ & 15.830 & 1.131 & 11.503 & 17.908 \\
\hline Log Unemployment Insurance Benefits & $97,802,424$ & 14.594 & 1.119 & 10.697 & 16.796 \\
\hline Log Other Welfare Benefits & $97,802,424$ & 17.923 & 0.978 & 14.056 & 19.657 \\
\hline Minimum Wage & $97,802,424$ & 7.481 & 0.813 & 6.266 & 11.409 \\
\hline
\end{tabular}

Notes. The data covers the years 1975-2004. All dollar values are converted into 2000 dollars to reflect real values.

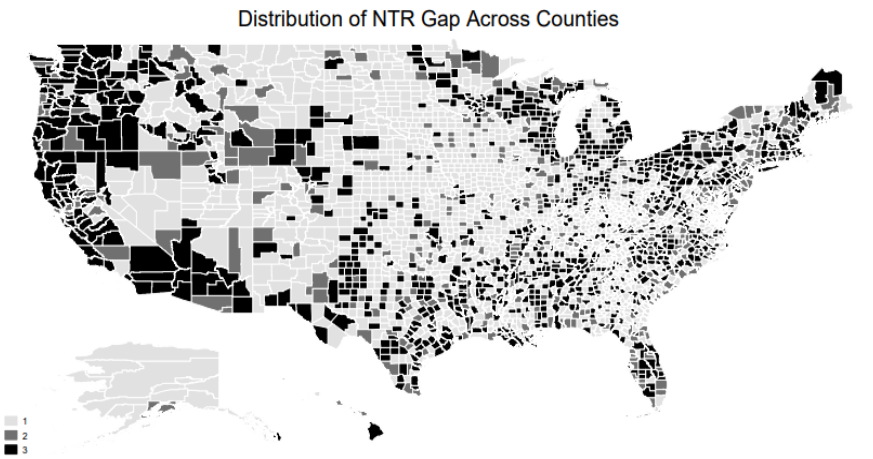

Figure 1 shows the geographic distribution of NTR-Gap across US counties. Counties in east, west, northeast, and southwest have higher NTR-Gaps. Figure 2 shows the cross-industry distribution of NTR and Non-NTR tariff rates before and after trade liberalization. The visually largest NTR-Gaps are observable for the manufacturing and mining industries.

Figure 1: Distribution of NTR Gap across US Counties 


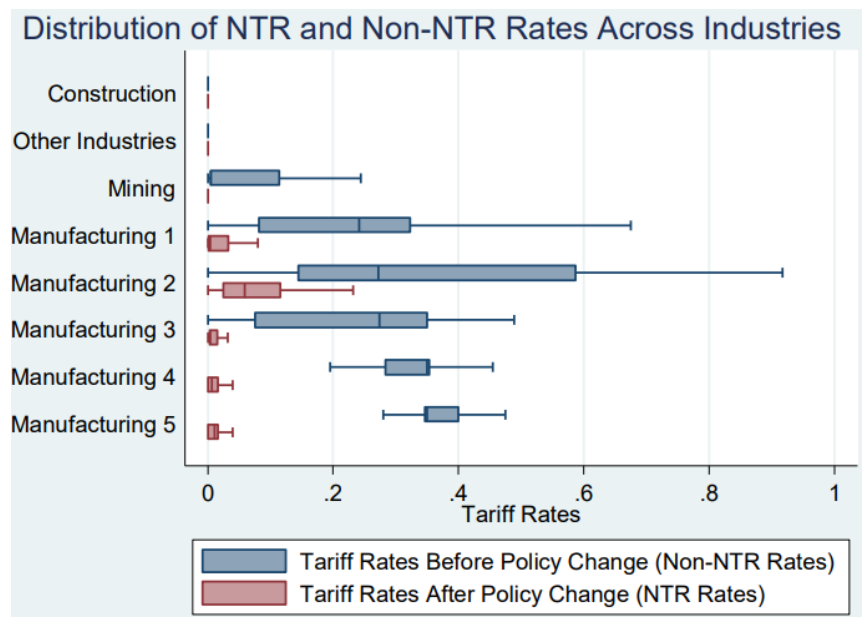

Figure 2: Differences in NTR Gap across Industries

\section{ECONOMETRIC METHOD}

Our identification strategy takes advantage of two sources of variation. First, the variations across industries in their exposure to the trade liberalization are based on the differences in NTR and Non-NTR tariff rates (i.e. NTRGap). The second source of variation is the counties' composition of industries before the trade liberalization. Therefore, we compare the birth outcomes of individuals in counties with higher exposure to the trade liberalization, i.e. higher NTR-Gap, to birth outcomes of mothers in counties with a lower exposure (first difference) after the trade liberalization, i.e. after 2000, to before trade liberalization (second difference).

The assumption behind the identification strategy is that in the absence of the policy change the outcomes of mothers in counties with higher NTR-Gap would have followed the same path and would have been influenced by the same determinants as the outcomes of mothers in counties with lower NTR-Gap. The exogeneity assumption lends itself to the fact that tariff rates for NonNTR status was set in the Smooth-Hawley Tariff Act of 1930 and modified slightly in 1948 when the US entered the General Agreement on Tariffs and Trade (GATT) [This organization later was changed to WTO]. About 79 percent of the variation in NTRGap is due to variations in Non-NTR rates set about 70 years ago. In another word, it is arguable that the differences between NTR and Non-NTR rates in the year 2000 across different industries, a gap that was set decades ago, were probably orthogonal to other determinants of birth outcomes. Moreover, the change in trade policy was mainly due to the entry of China into the WTO. This change and the proceeding trade boom was unprecedented and unanticipated. Also, mothers are less likely to be aware of the consequences nor could they predict the timing of such trade policy change. Therefore, it is less likely that they responded to the policy by selecting (or not selecting) themselves into the maternity ward. Thus, those determinants of birth outcomes could not have been a response or a result of the change in the trade policy. In summary, we use the following differencein-difference estimation strategy:

$$
\begin{gathered}
y_{i c s t}=\alpha_{1} \text { post }_{t} \times N T R \text { Gap }_{c}+\alpha_{2} \text { post }_{t} \times N T R_{c}+\alpha_{3} N T R \text { Gap }_{c}+\alpha_{4} N T R_{c}+\alpha_{5} X_{i} \\
+\alpha_{6} Z_{c s t}+\xi_{c}+\zeta_{t}+\eta_{s} \times T+\epsilon_{i c s t}
\end{gathered}
$$

Where $y y$ is the birth outcome of mother $i$ in county $c$ in state $s$ and time (year-by-month) $t$. The variable post is a dummy that equals one if the year of observation is after 2000 and zero otherwise. In $X$, we include a series of parental characteristics (Dummies for mother's education, race, marital status, and age as well as dummies for father's race and age). In $Z$ is included a series of county and state covariates that vary by year (These covariates include unemployment rate, labor force participation rate, log of county population, average weekly wages, real GSP per capita, real personal income per capita, percentage blacks, percentage whites, percentage males, percentage population aged 25-65, Log Current Transfer Receipt, Log Income Maintenance Benefits, Log Unemployment Insurance Benefits, Log Other Welfare Benefits, and minimum wage). The matrices $\xi$ and $\zeta$ represent the county and year-by month fixed effects. In some specifications, we also include a state by year trend $\left(\eta_{s} \times T\right)$. In this formulation, the coefficient of interest is $\alpha_{1}$.

The parameter $N T R$ represents a weighted average of NTR rates across industries in county $c$. Similarly, NTR - Gap is the weighted average of the gap across industries based on their initial employment as a portion of the county's employment. In order to construct this weighted mean, we first calculate the NTR-Gap for each industry $j$, as follows:

$N T R \operatorname{Gap}_{j}=$ Non $-N T R_{j}-N T R_{j}$

Following the recent literature (Autor et al., 2019; Feler and Senses, 2017; Pierce and Schott, 2020), we compute the share of each industry in county's employment and use this share as a weight to calculate the NTR-Gap of the county, as follows:

$N T R \operatorname{Gap}_{c}=\sum_{j} \frac{E_{j c}^{1990}}{E_{c}^{1990}} N T R \operatorname{Gap}_{j}$

Where $E_{c}$ is total county employment and $E_{j c}$ is the employment in industry $\mathrm{j}$ and county $c$, both calculated at 1990 a period well before the trade policy change. This is done at the base year to avoid the concern that the county share of employment at each industry could change and respond as a prediction of the trade policy change.

Figure 3 illustrates the pre-trend and post-trend (where the threshold year is 2000) of employment growth for industries with zero and positive NTR-Gap. There are no visually obvious differences between the pre-trend in the growth of the two sets of industries ruling out the concerns regarding the pre-trend and already existing differences in these industries that helped the divergence of birth outcomes. As expected, after 2000 the two sets of industries started to diverge as the trade affected the employment of industries with positive NTR-Gap, those who were protected by the higher Non-NTR rates before the trade liberalization. 


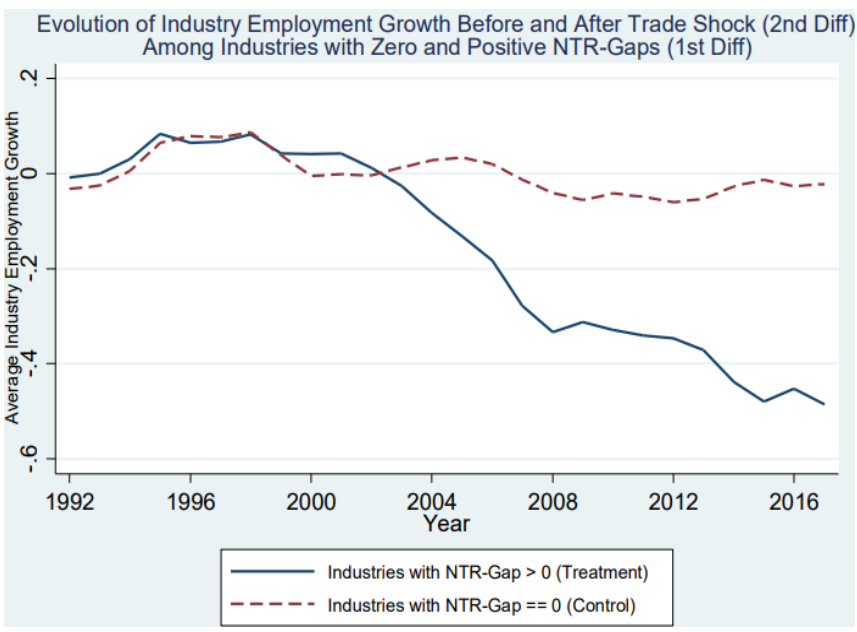

Figure 3: Pre-Trend and Post-Trends in Industries with Zero and Positive NTR Gap

While the main results are based on equation 1 we also attempt to re-evaluate the effect of trade liberalization on air quality, and industry-specific employment using the following county by-year fixed-effect models:

$$
\begin{gathered}
y_{c s t}=\alpha_{1} \text { post }_{t} \times N T R G a p_{c}+\alpha_{2} \text { post }_{t} \times N T R_{c}+\alpha_{3} N T R \operatorname{Gap}_{c}+\alpha_{4} N T R_{c}+\alpha_{5} Z_{c s t} \\
+\xi_{c}+\zeta_{t}+\eta_{s} \times T+\epsilon_{c s t}
\end{gathered}
$$

Where all parameters are as in equation 1 . Also, we reexamine the relationship between production and employment in the manufacturing sector on air quality using the following county by-year panel formulation:

$y_{c s t}=\alpha_{0}+\alpha_{1}$ Manufact $+\alpha_{5} Z_{c s t}+\xi_{c}+\zeta_{t}+\eta_{s} \times T+\epsilon_{c s t}$

Where $y$ is the standardized pollution explained in section 4 and Manufact is the share of employment in the manufacturing sector in the county's employment.

Since the main shocks occur at the county level, we cluster standard errors at the county. For county-by-year panel data models (equations 4 and 5), we weight the regressions using the average county population over the sample period. The sample covers the years 1990-2017.

Counties Reported Ozone in All Years, 1990-2017

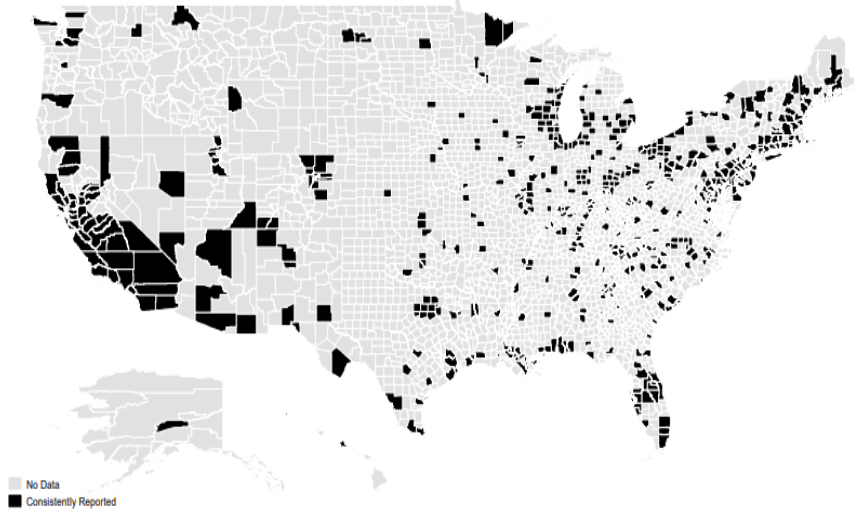

Figure 4: Distribution of Ozone Pollution Monitors across US Counties

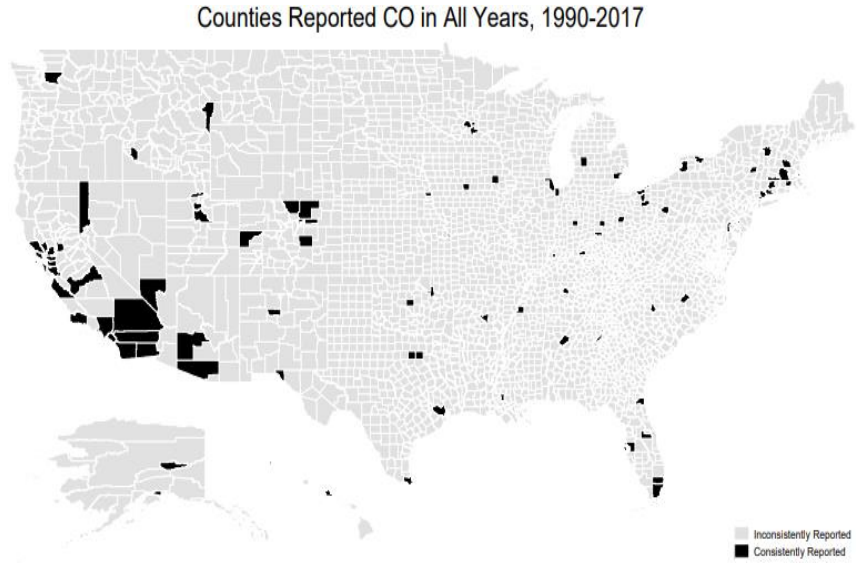

Figure 5: Distribution of Pollution Monitors that Consistently Reported CO over the Years 1990-2017

One might be concerned that a Two-Stage Least Square (2SLS) is a better approach in this context as the trade liberalization affects air pollution and air pollution impacts birth outcomes. There are two econometrically challenging issues with applying a 2SLS strategy in the current study. First, as we show in section 6 the trade liberalization affects air pollution which confirms the relevance assumption. However, it also affects a variety of socioeconomic features of the county which in turn affects birth outcomes. Therefore, the exclusion restriction assumption is violated and makes the NTR-Gap an inappropriate instrument. Second, the distribution of pollution monitors across US counties is sparse and the periodic report of the pollutants is sporadic. Figure 4 and Figure 5 show the geographic distribution of those pollution monitors that consistently reported Ozone and $\mathrm{CO}$, respectively. For instance, only 119 monitors reported $\mathrm{CO}$ at least once a year but consistently over the years 1990-2017 which are roughly 4 percent of all US counties. This fact leaves us with a very small sub-sample of the original data. For these two reasons, we prefer a reduced-form analysis as introduced in equation 1 and widely implemented in the literature (Autor et al., 2019; Feler and Senses, 2017; Pierce and Schott, 2020).

\section{Discussion On THE Main Results}

We start by evaluating the effect of trade liberalization on the economic characteristics of counties using equation 4 . Table 2 shows the results for the coefficient of interest, 1 , in panel $\mathrm{A}$ and adding a state trend in panel $\mathrm{B}$. using the standard deviation of NTR-Gap ( 0.18 percent) as the main shock, a one standard deviation change in NTR-Gap is associated with 2.8 percent reduction in annual wages, 3.6 percent reduction in total employment, 0.6 percent decrease in manufacturing employment, and 0.05 percent rise in the local unemployment rate. Similar findings are also documented by other studies (Autor et al., 2019; Feler and Senses, 2017; Pierce and Schott, 2020). 
Table 2: Trade Liberalization and Counties' Socioeconomic Characteristics

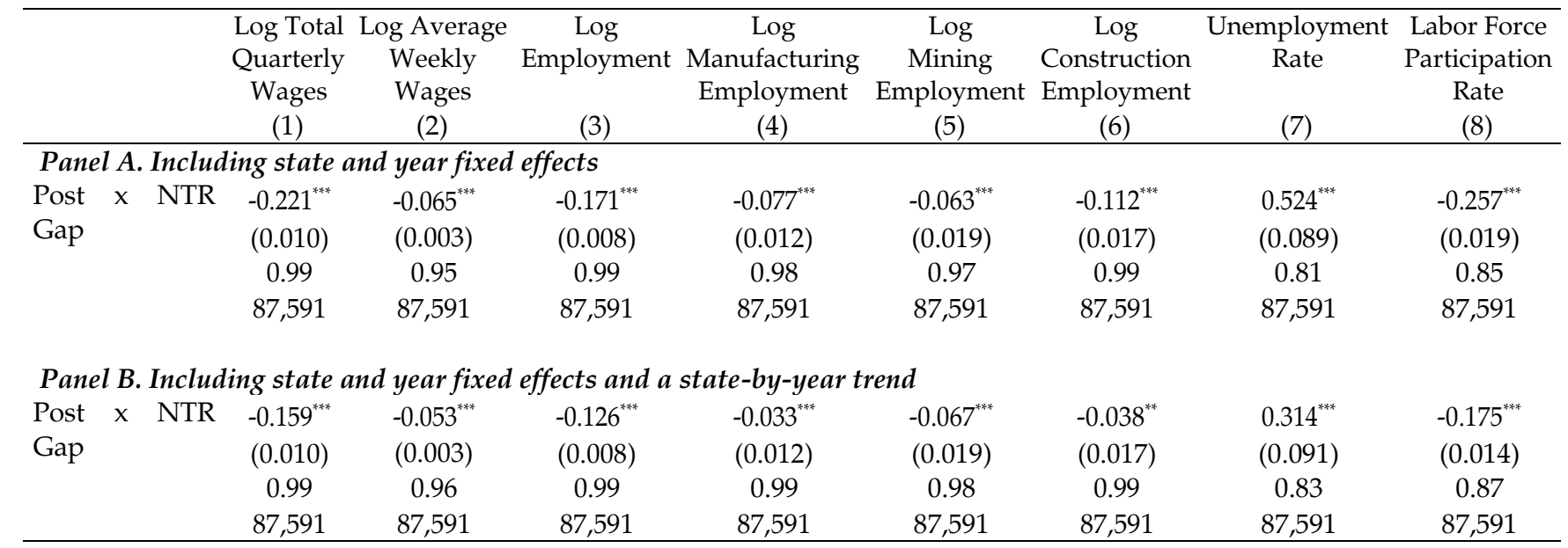

Notes. Standard errors, reported in parentheses, are clustered on the county. All regressions are weighted by the average county population over the sample period.

Next, we re-evaluate the literature on the pollution effects of manufacturing employment as the largest NTR-Gap is observed in this industry. Using equation 5 Table 3 shows the results of county-by-year regressions that include county and year fixed effects (panel A) and a state-by-year trend (panel B) for various pollutants in columns. Note that to ease the interpretations and make the results intuitive, we have standardized the pollutant variables. Regardless of including a state trend, all marginal effects are economically sizeable and statistically significant. For instance, a 10 percent rise in the share of manufacturing employment in county's employment is associated with 0.86 standard deviation rise in Ozone, 0.55 standard deviation rise in sulfur dioxide, 0.18 standard deviation rise in particulate matters less than 10 micrometers (PM10), and 0.19 standard deviation rise in PM2.5 (columns 1, 5, 7, and 8 , respectively). The literature also confirms the link between manufacturing production and pollution (Beach and Hanlon, 2016; Hilaly and Sikdar, 1994; Larsson, 2014; Levinson, 2009; Tavassoli et al., 2020; Zaim, 2004).

Table 3: The Effect of Manufacturing Employment on Air Pollution

\begin{tabular}{|c|c|c|c|c|c|c|c|c|}
\hline & $\begin{array}{c}\text { Log Total } \\
\text { Quarterly } \\
\text { Wages }\end{array}$ & $\begin{array}{c}\text { Log } \\
\text { Average } \\
\text { Weekly } \\
\text { Wages }\end{array}$ & $\begin{array}{c}\text { Log } \\
\text { Employment }\end{array}$ & $\begin{array}{c}\log \\
\text { Manufacturing } \\
\text { Employment }\end{array}$ & $\begin{array}{l}\text { Log Mining } \\
\text { Employment }\end{array}$ & $\begin{array}{c}\text { Log } \\
\text { Construction } \\
\text { Employment }\end{array}$ & $\begin{array}{c}\text { Unemployment } \\
\text { Rate }\end{array}$ & $\begin{array}{c}\text { Labor Force } \\
\text { Participation } \\
\text { Rate }\end{array}$ \\
\hline & (1) & (2) & (3) & (4) & (5) & (6) & (7) & (8) \\
\hline \multicolumn{9}{|c|}{ Panel A. Including state and year fixed effects } \\
\hline Post $\times$ NTR & $-0.221^{* * *}$ & $-0.065^{* * *}$ & $-0.171^{* * *}$ & $-0.077^{* * *}$ & $-0.063^{* * *}$ & $-0.112^{* * *}$ & $0.524^{* * *}$ & $-0.257^{* * *}$ \\
\hline Gap & $(0.010)$ & $(0.003)$ & $(0.008)$ & $(0.012)$ & $(0.019)$ & $(0.017)$ & $(0.089)$ & $(0.019)$ \\
\hline$R^{2}$ & 0.99 & 0.95 & 0.99 & 0.98 & 0.97 & 0.99 & 0.81 & 0.85 \\
\hline Observations & 87,591 & 87,591 & 87,591 & 87,591 & 87,591 & 87,591 & 87,591 & 87,591 \\
\hline \multicolumn{9}{|c|}{ Panel B. Including state and year fixed effects and a state-by-year trend } \\
\hline Post $\times$ NTR & $-0.159^{* * *}$ & $-0.053^{* * *}$ & $-0.126^{* * *}$ & $-0.033^{* * *}$ & $-0.067^{* * *}$ & $-0.038^{* *}$ & $0.314^{* * *}$ & $-0.175^{* * *}$ \\
\hline Gap & $(0.010)$ & $(0.003)$ & $(0.008)$ & $(0.012)$ & $(0.019)$ & $(0.017)$ & $(0.091)$ & $(0.014)$ \\
\hline$R^{2}$ & 0.99 & 0.96 & 0.99 & 0.99 & 0.98 & 0.99 & 0.83 & 0.87 \\
\hline Observations & 87,591 & 87,591 & 87,591 & 87,591 & 87,591 & 87,591 & 87,591 & 87,591 \\
\hline
\end{tabular}

Notes. Standard errors, reported in parentheses, are clustered on the county. All regressions are weighted by the average county population over the sample period.

Therefore, one would expect that the liberalization in trade changes the air quality in local areas that were affected by the subsequent import competition. Table 4 shows the results using equation 4 and replacing the outcome with a series of criteria pollutant measures. Looking at the estimated effects in panel B that includes a state-by-year trend, a one standard deviation change in NTR-Gap is associated with 1.5 standard deviation reduction in Ozone and 0.05 standard deviation reduction in carbon monoxide (columns 1 and 2, respectively). These results are in line with the studies on environmental benefits of trade liberalization (Cherniwchan, 2017; Forslid et al., 2017; Gale IV, 1995). 
Table 4: Trade Liberalization and Air Pollution

\begin{tabular}{|c|c|c|c|c|c|c|c|c|}
\hline & Ozone & $\begin{array}{l}\text { Carbon } \\
\text { Monoxide }\end{array}$ & $\begin{array}{l}\text { Nitrogen } \\
\text { Monoxide }\end{array}$ & $\begin{array}{l}\text { Nitrogen } \\
\text { Dioxide }\end{array}$ & $\begin{array}{c}\text { Sulfur } \\
\text { Dioxide }\end{array}$ & N-hexane & $\mathrm{PM}_{10}$ & $\mathrm{PM}_{2.5}$ \\
\hline & $(1)$ & $(2)$ & (3) & (4) & $(5)$ & $(6)$ & (7) & (8) \\
\hline \multicolumn{9}{|c|}{ Panel A. Including state and year fixed effects } \\
\hline Post $\times$ NTR & $-8.887^{* * *}$ & $-0.261^{* * *}$ & $-3.005^{*}$ & $-3.500^{* * *}$ & $-3.882^{* * *}$ & $-0.609^{* * *}$ & $-18.125^{* * *}$ & $-8.514^{* * *}$ \\
\hline Gap & $(2.367)$ & $(0.056)$ & $(1.605)$ & $(1.010)$ & $(0.582)$ & $(0.171)$ & $(6.908)$ & $(3.243)$ \\
\hline$R^{2}$ & 0.82 & 0.78 & 0.81 & 0.49 & 0.75 & 0.70 & 0.42 & 0.54 \\
\hline Observations & 18,663 & 6,260 & 5,447 & 6,596 & 9,430 & 2,417 & 16,589 & 19,573 \\
\hline \multicolumn{9}{|c|}{ Panel B. Including state and year fixed effects and a state-by-year trend } \\
\hline Post $\times$ NTR & $-8.333^{* * *}$ & $-0.264^{* * *}$ & $-2.846^{*}$ & $-2.749^{* * *}$ & $-2.596^{* * *}$ & $-0.584^{* * *}$ & $-17.248^{* * *}$ & $-6.524^{* * *}$ \\
\hline Gap & $(2.290)$ & $(0.066)$ & $(1.485)$ & $(1.155)$ & $(0.651)$ & $(0.136)$ & $(6.589)$ & $(3.105)$ \\
\hline$R^{2}$ & 0.83 & 0.79 & 0.86 & 0.51 & 0.76 & 0.76 & 0.43 & 0.55 \\
\hline Observations & 18,663 & 6,260 & 5,447 & 6,596 & 9,430 & 2,417 & 16,589 & 19,573 \\
\hline
\end{tabular}

Notes. Standard errors, reported in parentheses, are clustered on the county. All regressions are weighted by the average county population over the sample period.

Finally, we turn our focus to the reduced form effects of trade liberalization on birth outcomes applying equation 1 . The main results are reported in Table 5. Panel A includes a full set of fixed effects and controls as explained in section 4 while panel B adds a state-by-year trend. The marginal effects and their statistical significance are quite similar in both panels. Focusing on the coefficients in panel B, one standard deviation in NTR-Gap (0.18 percent change) is associated with 15 grams higher birth weight (column 1), 2.1 percentage points lower likelihood of low birth weight (column 3), 1.5 days higher gestational age (column 6), 2.3 percentage point lower probability of a preterm birth (column 7), and 1.8 percentage point reduction in the probability of an incidence of the low Apgar score (column 7). Comparing the estimated marginal effects with their mean, these effects are equivalent to a 0.5 percent increase from the mean of birth weight, 29.2 percent decrease from the mean of low birth weight, 0.6 percent increase from the mean of gestational age, 12.9 percent reduction from the mean of preterm birth, and 58.1 percent reduction from the mean of the low Apgar score. All the marginal effects are economically sizeable and statistically significant at conventional levels.

Table 5: Trade Liberalization and Infants' Health Outcomes

\begin{tabular}{|c|c|c|c|c|c|c|c|c|c|c|}
\hline & $\begin{array}{c}\text { Birth } \\
\text { Weight }\end{array}$ & $\begin{array}{l}\text { Term Birth } \\
\text { Weight }\end{array}$ & $\begin{array}{l}\text { Low Birth } \\
\text { Weight }\end{array}$ & $\begin{array}{c}\text { Very Low } \\
\text { Birth } \\
\text { Weight }\end{array}$ & $\begin{array}{c}\text { Small for } \\
\text { Gestational } \\
\text { Age }\end{array}$ & $\begin{array}{l}\text { Gestational } \\
\text { Age }\end{array}$ & $\begin{array}{l}\text { Preterm } \\
\text { Birth }\end{array}$ & $\begin{array}{l}\text { Apgar } \\
\text { Score }\end{array}$ & $\begin{array}{l}\text { Low Apgar } \\
\text { Score }\end{array}$ & $\begin{array}{l}\text { Fetal } \\
\text { Growth }\end{array}$ \\
\hline & $(1)$ & $(2)$ & (3) & (4) & $(5)$ & (6) & $(7)$ & $(8)$ & $(9)$ & $(10)$ \\
\hline \multicolumn{11}{|c|}{ Panel A. Including state and year fixed effects, parental controls, and state and county controls } \\
\hline $\begin{array}{l}\text { Post } \times \text { NTR } \\
\text { Gap }\end{array}$ & $\begin{array}{l}96.804^{* * *} \\
(21.958)\end{array}$ & $\begin{array}{l}52.813^{* *} \\
(22.987)\end{array}$ & $\begin{array}{c}-0.124^{* * *} \\
(0.029)\end{array}$ & $\begin{array}{c}-0.188^{* *} \\
(0.086)\end{array}$ & $\begin{array}{c}-0.116^{* * *} \\
(0.019)\end{array}$ & $\begin{array}{l}0.916^{* * *} \\
(0.124)\end{array}$ & $\begin{array}{c}-0.139^{* * *} \\
(0.036)\end{array}$ & $\begin{array}{l}0.719^{* * *} \\
(0.100)\end{array}$ & $\begin{array}{c}-0.094^{* * *} \\
(0.007)\end{array}$ & $\begin{array}{l}2.3327^{*} \\
(1.1452)\end{array}$ \\
\hline$R^{2}$ & 0.048 & 0.053 & 0.016 & 0.006 & 0.018 & 0.025 & 0.019 & 0.019 & 0.008 & 0.057 \\
\hline Observations & $97,802,424$ & $73,571,804$ & $97,802,424$ & $97,802,424$ & $97,802,424$ & $97,802,424$ & $97,802,424$ & $84,604,624$ & $84,604,624$ & $97,802,424$ \\
\hline \multicolumn{11}{|c|}{ Panel B. Including state and year fixed effects, parental controls, state and county controls, and state-by-year trend } \\
\hline $\begin{array}{l}\text { Post } \times \text { NTR } \\
\text { Gap }\end{array}$ & $\begin{array}{l}83.259^{* * *} \\
(25.391)\end{array}$ & $\begin{array}{l}48.646^{*} \\
(25.281)\end{array}$ & $\begin{array}{c}-0.115^{* * *} \\
(0.036)\end{array}$ & $\begin{array}{l}-0.105 \\
(0.097)\end{array}$ & $\begin{array}{c}-0.178^{* * *} \\
(0.023)\end{array}$ & $\begin{array}{l}1.243^{* * *} \\
(0.156)\end{array}$ & $\begin{array}{c}-0.127^{* * *} \\
(0.042)\end{array}$ & $\begin{array}{l}0.895^{* * *} \\
(0.174)\end{array}$ & $\begin{array}{c}-0.100^{* * *} \\
(0.011)\end{array}$ & $\begin{array}{l}2.193^{*} \\
(1.012)\end{array}$ \\
\hline$R^{2}$ & 0.058 & 0.062 & 0.018 & 0.008 & 0.025 & 0.026 & 0.027 & 0.023 & 0.009 & 0.059 \\
\hline Observations & $97,802,424$ & $73,571,804$ & $97,802,424$ & $97,802,424$ & $97,802,424$ & $97,802,424$ & $97,802,424$ & $84,604,624$ & $84,604,624$ & $97,802,424$ \\
\hline
\end{tabular}

Notes. Robust standard errors, reported in parentheses, are clustered on the county. Parental controls include: mother and father race and age dummies, mother's education dummies, and mother's marital status. State-by- year and countyby-year controls include: unemployment rate, labor force participation rate, log of county population, average weekly wages, real GSP per capita, real personal income per capita, percentage blacks, percentage whites, percentage males, percentage population aged 25-65, Log Current Transfer Receipt, Log Income Maintenance Benefits, Log Unemployment Insurance Benefits, Log Other Welfare Benefits, and minimum wage. The outcomes are defined in the text.

The results of Table 5 are robust with and without parental and county controls (not shown here). The results are also robust and slightly larger at the extensive margin where we eliminate counties with NTR-Gap of zero. The effects are larger among low educated black mothers and states at the bottom half of personal income per capita distribution (The results are not shown here but available upon request).

\section{CONCLUSION}

One of the ongoing debates regarding globalization and free trade is their potential effects on the environment, and as a result, on the health of individuals. From a policymaker's perspective, understanding the environmental and health externalities of free trade is important to find the optimal levels of tariffs and the degree to which the economy should be open to trade. This 
paper aimed to serve this purpose by exploring the effects of US-China trade liberalization on pollution and infants' health outcomes. First, we implemented a series of countyby-year panel data fixed effect models and documented three facts: 1) trade liberalization has adverse effects on the local economy. Specifically, it lowers employment in manufacturing, mining, and construction industries. 2) Production in manufacturing industries is associated with higher levels of pollution including Ozone, CO, PM10, and PM2.5, pollutants that are shown to have negative effects on birth outcomes. 3) trade liberalization reduces pollution at the county level through reductions in manufacturing and mining industries.

Next, we used the universe of birth records in the US over the years 1990-2017 (over 97 million observations) and applied a difference-in-difference identification strategy, and documented that trade liberalization has positive effects on birth outcomes. The effects are robust across specifications, sub-samples, and a wide range of health outcomes. The marginal effects are economically sizeable and statistically significant. A 1 percent reduction in tariff rates is associated with an 11.5 and 12.7 percentage point reduction in the likelihood of low birth weight and preterm birth, respectively. Overall, we established the fact that trade liberalization improves air quality and has potential positive externalities for infants' health.

\section{References}

Aizer, A., and McLanahan, S. (2006). The impact of child support enforcement on fertility, parental investments, and child well-being. Journal of Human Resources, 41(1), 28-45. https://doi.org/10.3368/jhr.XLI.1.28

Almond, D., and Currie, J. (2011a). Human capital development before age five. In Handbook of Labor Economics (Vol. 4, Issue PART B). Elsevier. https://doi.org/10.1016/S0169$\underline{\text { 7218(11)02413-0 }}$

Almond, D., and Currie, J. (2011b) . Killing me softly: The fetal origins hypothesis. Journal of Economic Perspectives, 25(3), 153-172. https://doi.org/10.1257/jep.25.3.153

Antweiler, W., Copeland, B. R., and Taylor, M. S. (2001). Is free trade good for the environment? American Economic Review, 91(4), 877-908. https://doi.org/10.1257/aer.91.4.877

Autor, D., Dorn, D., and Hanson, G. (2019). When Work Disappears: Manufacturing Decline and the Falling Marriage Market Value of Young Men. American Economic Review: Insights, $1(2)$,

161-178. https://doi.org/10.1257/aeri.20180010

Barker, D. J. (1990). The fetal and infant origins of adult disease. BMJ: British Medical Journal, 301(6761), 1111.

Beach, B., and Hanlon, W. W. (2016). Coal smoke and mortality in an early industrial economy. The Economic Journal.

Benarroch, M., and Gaisford, J. (2014). Intra-industry Trade Liberalization and the Environment. Review of International Economics, 22(5), https://doi.org/10.1111/roie.12143
Chatterji, P., Lahiri, K., and Kim, D. (2014). Fetal growth and neurobehavioral outcomes in childhood. Economics and Human Biology, 15, 187-200. https://doi.org/10.1016/j.ehb.2014.09.002

Cherniwchan, J. (2017). Trade liberalization and the environment: Evidence from NAFTA and U.S. manufacturing. Journal of International Economics, 105, 130-149. https://doi.org/10.1016/j.jinteco.2017.01.005

Chou, S. Y., Liu, J. T., Grossman, M., and Joyce, T. (2010). Parental education and child health: Evidence from a natural experiment in Taiwan. American Economic Journal: Applied Economics, 2(1), 33-61. https://doi.org/10.1257/app.2.1.33

Colantone, I., and Stanig, P. (2018). The Trade Origins of Economic Nationalism: Import Competition and Voting Behavior in Western Europe. American Journal of Political Science, 62(4), 936-953. https://doi.org/10.1111/ajps.12358

Cole, N., and Currie, J. (1993). Welfare and child health: The link between AFDC participation and birth weight. American Economic Review, 83(4), 971-985. https://doi.org/10.2307/2117589

Copeland, B. R. (2013). Trade and the Environment. Palgrave Handbook of International Trade, 423-496. https://doi.org/10.1007/978-0-230-30531-1_15

Corman, H., Dave, D., Reichman, N. E., Corman, H., Dave, D., and Reichman, N. E. (2019). The Effects of Prenatal Care on Birth Outcomes: Reconciling a Messy Literature. In Oxford Research Encyclopedia of Economics and Finance. Oxford University Press. https://doi.org/10.1093/acrefore/9780190625979.013.375

Currie, J., and Moretti, E. (2003). Mother's Education and the Intergenerational Transmission of Human Capital: Evidence from College Openings. The Quarterly Journal of Economics, 118(4),

1495-1532. https://doi.org/10.1162/003355303322552856

Currie, Janet, Neidell, M., and Schmieder, J. F. (2009). Air pollution and infant health: Lessons from New Jersey. Journal of Health Economics, 28(3), 688-703. https://doi.org/10.1016/j.jhealeco.2009.02.001

Dix-Carneiro, R., Soares, R. R., and Ulyssea, G. (2018). Economic shocks and crime: Evidence from the Brazilian trade liberalization. American Economic Journal: Applied Economics, 10(4), 158-195. https://doi.org/10.1257/app.20170080

Ederington, J., Levinson, A., and Minier, J. (2004). Trade liberalization and pollution havens. In Advances in Economic Analysis and Policy (Vol. 4, Issue 2). Berkeley Electronic Press. https://doi.org/10.2202/1538-0637.1330

Feenstra, R., Romalis, J., and Schott, P. (2002). U.S. Imports, Exports, and Tariff Data, 1989-2001. https://doi.org/10.3386/w9387

Feler, L., and Senses, M. Z. (2017). Trade shocks and the provision of local public goods. American Economic Journal: Economic Policy, 9(4), 101-143. https://doi.org/10.1257/pol.20150578

Feng, J., Xie, Q., and Zhang, X. (2021). Trade liberalization and the health of working-age adults: Evidence from China. World Development, 139, 105344. https://doi.org/10.1016/j.worlddev.2020.105344

Figlio, D., Guryan, J., Karbownik, K., and Roth, J. (2014). The effects of poor neonatal health on children's cognitive development? American Economic Review, 104(12), 4205-4230. https://doi.org/10.1257/aer.104.12.3921 
Forslid, R., Okubo, T., and Sanctuary, M. (2017). Trade Liberalization, Transboundary Pollution, and Market Size. Journal of the Association of Environmental and Resource Economists, 4(3), 927-957. https://doi.org/10.1086/693562

Fung, K. C., and Maechler, A. M. (2007). Trade liberalization and the environment: The case of intra-industry trade. Journal of International Trade and Economic Development, 16(1), 53-69. https://doi.org/10.1080/09638190601165509

Gage, T. B., Fang, F., O'Neill, E., and DiRienzo, G. (2013). Maternal Education, Birth Weight, and Infant Mortality in the United States. Demography, 50(2), 615-635. https://doi.org/10.1007/s13524-012-0148-2

Gale IV, L. R. (1995). Trade Liberalization and Pollution: An Input-Output Study of Carbon Dioxide Emissions in Mexico. Economic Systems Research, 7(3), 309-320. https://doi.org/10.1080/09535319500000026

Ghani, G. M. (2012). Does trade liberalization effect energy consumption? Energy Policy, 43, 285-290. https://doi.org/10.1016/j.enpol.2012.01.005

Hilaly, A. K., and Sikdar, S. K. (1994). Pollution balance: A new methodology for minimizing waste production in manufacturing processes. Journal of the Air and Waste Management Association, 44(11), 1303-1308. https://doi.org/10.1080/10473289.1994.10467325

Hill, E. L. (2018). Shale gas development and infant health: Evidence from Pennsylvania. Journal of Health Economics, 61, 134-150. https://doi.org/10.1016/j.jhealeco.2018.07.004

Hoynes, H., Miller, D., and Simon, D. (2015). Income, the earned income tax credit, and infant health. American Economic Journal: Economic Policy, 7(1), 172-211. https://doi.org/10.1257/pol.20120179

$\mathrm{Hu}, \mathrm{B}$. , and McKitrick, R. (2016). Decomposing the Environmental Effects of Trade Liberalization: The Case of ConsumptionGenerated Pollution. Environmental and Resource Economics, 64(2), 205-223. https://doi.org/10.1007/s10640-014-9865-x

Hubbard, T. P. (2014). Trade and transboundary pollution: quantifying the effects of trade liberalization on $\mathrm{CO} 2$ emissions. Applied Economics, 46(5), 483-502. https://doi.org/10.1080/00036846.2013.857000

Joyce, T. (1999). Impact of augmented prenatal care on birth outcomes of Medicaid recipients in New York City. Journal of Health Economics, 18(1), 31-67. https://doi.org/10.1016/S0167-6296(98)00027-7

Larsson, D. G. J. (2014). Pollution from drug manufacturing: review and perspectives. Philosophical Transactions of the Royal Society B: Biological Sciences, 369(1656), 20130571. https://doi.org/10.1098/rstb.2013.0571

Leonard, J., and Mas, A. (2008). Welfare reform, time limits, and infant health. Journal of Health Economics, 27(6), 1551-1566. https://doi.org/10.1016/j.jhealeco.2008.05.013

Levinson, A. (2009). Technology, international trade, and pollution from US manufacturing. American Economic Review, 99(5), 2177-2192. https://doi.org/10.1257/aer.99.5.2177

Lindo, J. M. (2011). Parental job loss and infant health. Journal of Health Economics, 30(5), 869-879. https://doi.org/10.1016/j.jhealeco.2011.06.008

Noghani, F., and Noghanibehambari, H. (2019). Product Market Competition, Corporate Governance, and Managerial Slack: Evidence from Trade Liberalization. Journal of Leadership,
Accountability
and
Ethics,
$16(4)$.

https://doi.org/10.33423/ilae.v16i4.2372

NoghaniBehambari, H., Noghani, F., and Tavassoli, N. (2020). Early Life Income Shocks and Old-Age Cause-Specific Mortality. Economic Analysis, 53(2), 1-19.

NoghaniBehambari, H., Noghani, F., Tavassoli, N., and Toranji, M. (2020). Long Term Effects of in Utero Exposure to "The Year without a Summer." SSRN Electronic Journal. https://doi.org/10.2139/ssrn.3668739

Noghanibehambari, H., and Salari, M. (2020). Health benefits of social insurance. Health Economics.

Olper, A., Curzi, D., and Swinnen, J. (2018). Trade liberalization and child mortality: A Synthetic Control Method. World Development, 110, 394-410. https://doi.org/10.1016/j.worlddev.2018.05.034

Pierce, J. R., and Schott, P. K. (2020). Trade Liberalization and Mortality: Evidence from US Counties. American Economic Review: Insights, 2(1), 47-63. https://doi.org/10.1257/aeri.20180396

Pierson, K., Hand, M. L., and Thompson, F. (2015). The government finance database: A common resource for quantitative research in public financial analysis. PLOS ONE, 10(6). https://doi.org/10.1371/journal.pone.0130119

Rosenzweig, M. R., and Wolpin, K. I. (1995). Sisters, Siblings, and Mothers: The Effect of Teen-Age Childbearing on Birth Outcomes in a Dynamic Family Context. Econometrica, 63(2), 303. https://doi.org/10.2307/2951628

Rossin, M. (2011). The effects of maternity leave on children's birth and infant health outcomes in the United States. Journal of Health Economics, 30(2), 221-239. https://doi.org/10.1016/j.jhealeco.2011.01.005

SEER. (2019). Surveillance, Epidemiology, and End Results (SEER) Program (www.seer.cancer.gov) Research Data (1975-2016). National Cancer Institute, DCCPS, Surveillance Research Program.

Shen, J. (2008). Trade liberalization and environmental degradation in China. Applied Economics, 40(8), 997-1004. https://doi.org/10.1080/00036840600771148

Sonchak, L. (2015). Medicaid reimbursement, prenatal care and infant health. Journal of Health Economics, 44, 10-24. https://doi.org/10.1016/j.jhealeco.2015.08.008

Tavassoli, N., Noghanibehambari, H., Noghani, F., and Toranji, M. (2020). Upswing in Industrial Activity and Infant Mortality during Late 19th Century US. Journal of Environments, 6(1), 1-13. https://doi.org/10.20448/journal.505.2020.61.1.13

Torche, F. (2011). The Effect of Maternal Stress on Birth Outcomes: Exploiting a Natural Experiment. Demography, 48(4), 14731491. https://doi.org/10.1007/s13524-011-0054-z

Wherry, L. R., Miller, S., Kaestner, R., and Meyer, B. D. (2018). Childhood medicaid coverage and later-life health care utilization. Review of Economics and Statistics, 100(2), 287-302. https://doi.org/10.1162/rest_a 00677

Zaim, O. (2004). Measuring environmental performance of state manufacturing through changes in pollution intensities: A DEA framework. Ecological Economics, 48(1), 37-47. https://doi.org/10.1016/j.ecolecon.2003.08.003

$--0-$ 